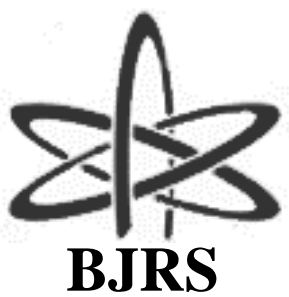

BRAZILIAN JOURNAL

$\mathrm{OF}$

RADIATION SCIENCES

07-02A (2019) 01-09

\title{
Antioxidant activity of Dianthus chinensis flowers processed by ionizing radiation
}

\author{
Koike $^{\text {a,b }}$ A. C. R.; Barros ${ }^{\text {b }, ~ L . ; ~ A n t o n i o ~}{ }^{\mathrm{b}}$, A. L.; Ferreira ${ }^{\mathrm{b}}$, I. C. F. R.; Villavicenci- \\ $\mathrm{O}^{\mathrm{a}}$, A. L. C. H. ${ }^{\mathrm{a}}$ \\ ${ }^{a}$ Nuclear and Energy Research Institute, National Commission of Nuclear Energy (IPEN-CNEN/SP), 05508-000, São \\ Paulo, SP, Brazil \\ ${ }^{b}$ Mountain Research Centre (CIMO), ESA, Polytechnic Institute of Bragança, 5301-855, Bragança, Portugal \\ amandaramos@usp.br
}

\begin{abstract}
Edible flowers are increasingly used in culinary preparations, which require new approaches to improve their conservation and safety. Irradiation treatment is safe and an effective alternative for food conservation. Indeed, it can also guarantee food quality, increasing shelf-life and disinfestation of it. This technology gives us a versatile way to get good quality food, reducing post-harvest losses. Dianthus chinensis flowers, popularly known as Chinese pink, are widely used in culinary preparations, being also acknowledged for their bioactive components and antioxidant properties. The purpose of this study was to evaluate the antioxidant activity of $D$. chinensis flowers submitted to electron beam and gamma irradiation at $0,0.5,0.8$ and $1 \mathrm{kGy}$. The antioxidant properties were evaluated through 2,2-diphenyl-1-picrylhydrazyl (DPPH) scavenging activity, reducing power and $\beta$ carotene bleaching inhibition assays. Total phenolics were also determined by the Folin-Ciocalteu assay. The antioxidant activity was higher for irradiated samples, especially those treated with 0.8 and $1 \mathrm{kGy}$, independently of the radiation source, which showed the highest capacity to inhibit $\beta$-carotene bleaching. Accordingly, the applied irradiation treatments seemed to represent feasible technology to preserve the quality of edible flower petals, being able to improve the antioxidant activity.
\end{abstract}

Keywords: edible flowers, Dianthus chinensis, ionizing radiation, antioxidant activity 


\section{INTRODUCTION}

The edible flower market is expanding in Brazil and in the world, due to the growing tendency of the application of flowers in the gastronomy and in recent years there has been an increase in consumption, generating an increase of varied and economic growth.

Edible flowers have been used for many years in culinary preparations for the purpose of adding beauty, aroma, color and flavor. Currently, this type of application in gastronomy aims to improve the sensory and nutritional quality of foods, since several species have biologically active substances [1-4].

Several studies showed that edible flowers are rich in bioactive compounds and contain numerous phytochemicals. Bioactive compounds are capable of acting in the prevention of chronic diseases such as cardiovascular, cancerous and age-related and degenerative diseases [4-6]

However, they are highly perishable product and must be free from diseases and insect pests, which is a challenge as they are usually grown without the use of pesticides. Its high perishability requires storage in small plastic containers in refrigerated environments, which represents an additional cost in the commercial chain. Various methods are applied by the food industry to increase the shelf life of food products as well as ensure their quality and safety [7-9]. Treatments capable of increasing shelf life and ensuring the safety of these products could be alternatives to minimize such problems [10].

Studies have shown that the application of the ionizing radiation is effective in the disinfestation, conservation as well as prolongation of the useful life of the food $[9,11]$.

International organizations encourage the adoption of international standards for phytosanitary measures, use of technology to prevent the introduction and dissemination of pests. Food irradiation is a postharvest quarantine treatment, effective in the disinfestation of food and to maintain its quality, approved in several countries [11-13]. Flowers are relatively sensitive to ionizing radiation and the sensitivity of cut flowers to the use of radiation varies from species to species $[14,15]$

Dianthus chinensis belongs to the family Caryophyllaceae, is native from Asia and Europe, popularly known as chinese pink or pink. Dianthus flowers are flattened with shades of white, pink,

purple and red or bicolor. The petals have a spicy flavor and are applied in salads, sandwiches, jellies, pies and in the aromatization of vinegar and wine [16-18]. 
Therefore, the purpose of this study was to evaluate the antioxidant activity of $D$. chinensis flowers submitted to electron beam and gamma irradiation at 0.5, 0.8 and $1.0 \mathrm{kGy}$ and control.

\section{MATERIALS AND METHODS}

\subsection{Sample}

Fresh edible flowers of $D$ chineses L. were purchased from a local market in São Paulo, Brazil. Chinese pink petals presenting different phenotypes (red, white, pink and multi-colored) were used.

\subsection{Sample irradiation}

\subsubsection{Gamma irradiation}

The samples were irradiated at the Nuclear and Energy Research Institute - IPEN - CNEN/SP (São Paulo, Brazil), using a ${ }^{60}$ Co source Gammacell 200 (Nordion Inc., Ottawa, ON, Canada), at room temperature $\left(25 \pm 2{ }^{\circ} \mathrm{C}\right)$, with a dose rate of $1.258 \mathrm{kGy} / \mathrm{h}$. Applied doses were $0.5,0.8$ and 1 kGy. Harwell Amber 3042 dosimeters were used to measure radiation dose. Non-irradiated samples were used as the control group. After irradiation, the samples were lyophilized (SL404, Solab, São Paulo, Brazil) and stored in a hermetically sealed package.

\subsubsection{Electron beam irradiation}

Samples were irradiated at the Nuclear and Energy Research Institute - IPEN - CNEN/SP (São Paulo, Brazil), using an electron beam accelerator (IBA Industrial Inc., Edgewood, NY, USA), at room temperature $\left(25 \pm 2^{\circ} \mathrm{C}\right.$ ). The applied doses were $0.5 \mathrm{kGy}$ (dose rate: $1.11 \mathrm{kGy} / \mathrm{s}$, energy: $1.400 \mathrm{MeV}$, beam current: $0.3 \mathrm{~mA}$, tray speed: $6.72 \mathrm{~m} / \mathrm{min}$ ), $0.8 \mathrm{kGy}$ (dose rate: $1.78 \mathrm{kGy} / \mathrm{s}$, energy: $1.400 \mathrm{MeV}$, beam current: $0.48 \mathrm{~mA}$, tray speed: $6.72 \mathrm{~m} / \mathrm{min}$ ) and $1.0 \mathrm{kGy}$ (dose rate: 2.23 kGy/s, energy: $1.400 \mathrm{MeV}$, beam current: $0.6 \mathrm{~mA}$, tray speed: $6.72^{\circ} \mathrm{m} / \mathrm{min}$ ). Non-irradiated samples were used as the control group. After irradiation, the samples were lyophilized (SL404, Solab, São Paulo, Brazil) and stored in a hermetically sealed package. 


\subsection{Antioxidant activity}

The extracts preparation and antioxidant activity were carried out at the Laboratory of Applied Chemistry and Biochemistry (LQBA) in the School of Agriculture of the Polytechnic Institute of Bragança - Portugal.

\subsubsection{Preparation of the extracts}

The methanol:water $(80: 20, \mathrm{v} / \mathrm{v})$ extract was prepared from lyophilized flowers. Samples $(\approx 0.5$ g) was stirred with $20 \mathrm{~mL}$ of the solvents mixture, at room temperature, $150 \mathrm{rpm}$ for $1 \mathrm{~h}$. The extract was filtered through Whatman No. 4 paper and the residue was re-extracted with $20 \mathrm{~mL}$ of methanol / water 80:20 (v/v). The combined hydromethanolic extracts were evaporated at $35^{\circ} \mathrm{C}$ (rotary evaporator Büchi R-210, Flawil, Switzerland) and lyophilized.

\subsubsection{DPPH radical -scavenging activity}

The DPPH (2,2-diphenyl-1-picryl-hydrazyl) radical scavenger activity was evaluated according to a methodology described [19]. The samples $(30 \mu \mathrm{L})$ of different concentrations of the extract solutions were added to the wells of a 96 well microplate with the methanolic solution $(270 \mu \mathrm{L})$ containing DPPH radicals $\left(6 \times 10^{-5} \mathrm{~mol} / \mathrm{L}\right)$. The mixture was left to stand in the dark for 30 minutes, and the absorbance was measured at $515 \mathrm{~nm}$ by using an ELX800 microplate reader (Bio-Tek Instruments, Inc; Winooski, USA).

\subsubsection{Reducing power}

Reduction power was evaluated according to a methodology described [20]. This methodology was performed using the Microplate Reader described above and measuring the absorbance at $690 \mathrm{~nm}$. The different concentrations of the extracts $(0.5 \mathrm{~mL})$ were mixed with sodium phosphate buffer $\left(200 \mathrm{mmol} \mathrm{L}^{-1}, \mathrm{pH} 6.6,0.5 \mathrm{~mL}\right)$ and potassium ferricyanide $(1 \% \mathrm{w} / \mathrm{v}, 0.5 \mathrm{~mL})$ and the mixture was incubated at $50{ }^{\circ} \mathrm{C}$ for $20 \mathrm{~min}$, and trichloroacetic acid $(10 \% \mathrm{w} / \mathrm{v}, 0.5 \mathrm{~mL})$ was added. The 
mixture $(0.8 \mathrm{~mL})$ was poured in the 48 -well plate, as also ferric chloride $(0.1 \% \mathrm{w} / \mathrm{v}, 0.16 \mathrm{~mL})$ and deionized water $(0.8 \mathrm{~mL})$.

\subsection{4 $\beta$-carotene/linoleate assay}

In the inhibition test of $\beta$-carotene discoloration, it was used by the method described [21]. A solution of $\beta$-carotene was prepared by dissolving $2 \mathrm{mg}$ of $\beta$-carotene in $10 \mathrm{~mL}$ of chloroform. Two milliliters of this solution were pipetted into a round-bottom flask. The chloroform was removed at $40^{\circ} \mathrm{C}$ under vacuum and linoleic acid (40 mg), Tween 80 emulsifier (400 mg), and distilled water $(100 \mathrm{~mL})$ were added to the flask with vigorous shaking. Aliquots $(4.8 \mathrm{~mL})$ of this emulsion were transferred into different test tubes containing $0.2 \mathrm{~mL}$ of different concentrations of the extract solutions. As soon as the emulsion was added to each tube, the zero time absorbance was measured at $470 \mathrm{~nm}$ (Analytik 200-2004 spectrophotometer, Jena, Germany) and tubes were shaken and incubated at $50^{\circ} \mathrm{C}$ in a bath for $2 \mathrm{~h}$ and the absorption was measured again.

\subsubsection{Total phenolics}

The total phenolics were determined by the Folin-Ciocalteu assay according to a methodology described [19]. The extract solution (1 mL) was mixed with Folin-Ciocalteu reagent (5 mL, previously diluted with water 1:10 v/v) and sodium carbonate $\left(75 \mathrm{~g} \mathrm{~L}^{-1}, 4 \mathrm{~mL}\right)$. The tubes were vortex mixed for $15 \mathrm{~s}$ and allowed to stand for $30 \mathrm{~min}$ at $40^{\circ} \mathrm{C}$ for color development. Absorbance was then measured at $765 \mathrm{~nm}$. Gallic acid was used to calculate the standard curve and the results were expressed as mg of gallic acid equivalents (GAE) per g of extract.

\subsection{Statistical Analysis}

The results of the color were submitted to analysis of variance (ANOVA) and Tukey test with significance level of $95 \%(\mathrm{P}<0.05)$.

\section{RESULTS AND DISCUSSION}

The results of the antioxidant activity of the extract of $D$. chinensis processed with electron beam and gamma irradiation are shown in Tables 1 and 2. 
Table 1: Antioxidant activity $\left(\mathrm{EC}_{50}\right.$ values, $\left.\mathrm{mg} / \mathrm{mL}\right)$ of $D$. chinensis extracts irradiated by

${ }^{60} \mathrm{Co}$ gamma-rays according to the irradiation dose

\begin{tabular}{lcccc}
\hline & \multicolumn{4}{c}{ EC50 values (mg/mL of extract) } \\
\hline \multirow{2}{*}{ Assays } & control & $\mathbf{0 . 5 ~ k G y}$ & $\mathbf{0 . 8 ~ k G y}$ & $\mathbf{1 . 0 ~ k G y}$ \\
\cline { 2 - 5 } \multicolumn{1}{c}{ Reducing power } & $0.81 \pm 0.01^{\mathrm{a}}$ & $0.83 \pm 0.01^{\mathrm{a}}$ & $0.75 \pm 0.01^{\mathrm{a}}$ & $0.95 \pm 0.02^{\mathrm{a}}$ \\
Folin-Ciocalteu assay* & $78.90 \pm 3.07^{\mathrm{a}}$ & $79.98 \pm 0.75^{\mathrm{a}}$ & $79.85 \pm 1.44^{\mathrm{a}}$ & $74.18 \pm 0.50^{\mathrm{a}}$ \\
DPPH & $1.53 \pm 0.03^{\mathrm{a}}$ & $1.66 \pm 0.03^{\mathrm{a}}$ & $1.43 \pm 0.03^{\mathrm{a}}$ & $1.67 \pm 0.06^{\mathrm{a}}$ \\
Inhibition of $\boldsymbol{\beta}$-carotene & $0.65 \pm 0.03^{\mathrm{a}}$ & $0.73 \pm 0.26^{\mathrm{a}}$ & $0.58 \pm 0.05^{\mathrm{a}}$ & $1.97 \pm 0.81^{\mathrm{b}}$ \\
bleaching & & & &
\end{tabular}

Mean \pm SD (Standard Deviation)

In each row different letters mean significant differences $(\mathrm{p}<0.05)$

* Results expressed in $\mathrm{mg}$ of gallic acid equivalents (GAE) per g of extract

Table 2: Antioxidant activity $\left(\mathrm{EC}_{50}\right.$ values, $\left.\mathrm{mg} / \mathrm{mL}\right)$ of $D$. chinensis extracts irradiated by electron beam according to the irradiation dose

\begin{tabular}{lcccc}
\hline \multirow{2}{*}{\multicolumn{1}{c}{ Assays }} & \multicolumn{4}{c}{ EC50 values (mg/mL of extract) } \\
\cline { 2 - 5 } & control & $\mathbf{0 . 5} \mathbf{~ k G y}$ & $\mathbf{0 . 8 ~ k G y}$ & $\mathbf{1 . 0 ~ k G y}$ \\
\hline Reducing power & $0.81 \pm 0.01^{\mathrm{a}}$ & $0.98 \pm 0.01^{\mathrm{a}}$ & $1.08 \pm 0.01^{\mathrm{a}}$ & $1.19 \pm 0.01^{\mathrm{a}}$ \\
Folin-Ciocalteu assay* & $78.90 \pm 3,07^{\mathrm{a}}$ & $84.46 \pm 0,97^{\mathrm{a}}$ & $74.61 \pm 0.98^{\mathrm{a}}$ & $71.83 \pm 1.07^{\mathrm{a}}$ \\
DPPH & $1.53 \pm 0.03^{\mathrm{a}}$ & $1.28 \pm 0.03^{\mathrm{a}}$ & $1.48 \pm 0.08^{\mathrm{a}}$ & $1.60 \pm 0.06^{\mathrm{a}}$ \\
Inhibition of $\boldsymbol{\beta}$-carotene & $0.65 \pm 0.03^{\mathrm{a}}$ & $0.58 \pm 0.01^{\mathrm{a}}$ & $2.17 \pm 0.02^{\mathrm{b}}$ & $2.16 \pm 0.11^{\mathrm{b}}$ \\
bleaching & & & &
\end{tabular}

Mean \pm SD (Standard Deviation)

In each row different letters mean significant differences $(p<0.05)$

*Results expressed in mg of gallic acid equivalents (GAE) per g of extract

Samples irradiated by electron beam with 0.8 and $1.0 \mathrm{kGy}$ showed the highest capacity to inhibit $\beta$-carotene bleaching inhibition. Concerning the effect of irradiation technology, only $\beta$ carotene bleaching inhibition was significantly different for gamma and electron-beam irradiated samples. Similar effects were observed in studies of influence of the irradiation process on antioxidant substances present in foods and edible flowers, which described a significant increase in 
the phenolic content of samples of petals Tropaeolum majus, Cammellia sinensis and Illx paraguariensis treated with maximum doses of $10.0 \mathrm{kGy}$ [22-24].

\section{CONCLUSION}

According to the results of the tests presented in the present work, it is concluded that the processing of the samples by radiation did not compromise an antioxidant activity of the edible flower species Chinese pink. Consequently, the applied irradiation treatments seemed to represent feasible technology to preserve the quality of edible flower petals

\section{ACKNOWLEDGMENT}

The authors are grateful to CNEN, CAPES, CNPq and IPEN-CNEN/SP for financial support. The Foundation for Science and Technology (FCT, Portugal) for financial support to CIMO (strategic project PEst-OE / AGR / UI0690 / 2014). This research is included in a Bilateral action CNPq FCT, Brazil/Portugal 2014.

\section{REFERENCES}

1. CREASY, R. The Edible Flowers Garden, Boston: Periplus Editions, 1999.

2. MLCEK, J., ROP, O. Fresh edible flowers of ornamental plants - A new source of nutraceutical foods. Trends Food Sci Technol, v. 22, p. 561-569, 2011.

3. FU, M. R., MAO, L. C. In vitro antioxidant activities of five cultivars of daylily flowers from China. Nat Prod Res, v. 22, p. 584 -591, 2008.

4. LOIZZO, M. R., PUGLIESE, A., BONESI, M.; TENUTA, M. C., MENICHINI, F., XIÃO, J., TUNDIS, R. Edible Flowers: A Rich Source of Phytochemicals with Antioxidant and Hypoglycaemic Activity. J Agric Food Chem, v. 64, p. 2467-2474, 2016.

5. LARA-CORTÉS, E., OSORIO-DÍAZ, P.; JIMÉNEZ-APARICIO; A., BAUTISTA-BAÑOS, S., Contenido nutricional, propiedades funcionales y conservación de flores comestibles. Revisión. Arch Latinoam Nutr, v. 63, p. 197-208, 2013.

6. IKRAM, E. H. K., ENG, K. H., JALIL, A. M. M., ISMAIL, A., IDRIS, S., AZLAN, A. Antioxidant capacity and total phenolic content of Malaysian underutilized fruits. J Food Compost Anal, v. 22, p. 388-393, 2009. 
7. KElley, K. M., CAMERON, A. C., BIERNBAUM, J. A., POFF, K. L. Effect of storage temperature on the quality of edible flowers. Postharvest Biol Technol, v. 27, p. 341-344, 2003.

8. NEWNAM, S. E., O’CONNER, A. S. Edible flowers. CSU Extension, n. 7237, Available at: <http://www.ext.colostate.edu/pubs/garden/07237.html, 2009> Last accessed: 20 jan. 2011.

9. FARKAS, J., MOHÁCSI-FARKAS, C. History and future of food irradiation. Trends Food Sci Technol, v. 20, p. 1-6, 2011.

10. ROP, O., MLCEK, J., JURIKOVA, T., NEUGEBAUEROVA, J., VABKOVA, J. Edible Flowers - A New Promising Source of Mineral Elements In Human Nutrition. Molecules, v. 17, p. 6672-6683, 2012.

11. TEETS, A. S., SUNDARARAMAN, M., WERE, L. M. Electron beam irradiated almond skin powder inhibition of lipid oxidation in coked salted ground chicken breast. Food Chemistry, v. 111, p. 934-941, 2008.

12. ANTONIO, A. L., CAROCHO, M., BENTO, A., QUINTANA, B., BOTELHO, M. L.; FERREIRA, I. C. F. R., Effects of gamma radiation on the biological, physico-chemical, nutritional and antioxidant parameters of chestnuts - A review. Food Chem Toxicol, v. 50, p. 3234-3242, 2012.

13. IAEA - INTERNATIONAL ATOMIC ENERGY AGENCY. Manual of Good Practice in Food Irradiation - Sanitary, Phytosanitary and Other Applications. Technical Reports Series, n 481, 2015.

14. KIKUCHI, O. K. Gamma and electron-beam irradiation of cut flowers. Radiat Phys Chem, v. 66, p. 77-79, 2003.

15. SANGWANANGKUL, P., SARADHUldhat, P., PAULL, R, E. Survey of tropical cut flower and foliage responses to irradiation. Postharvest Biol Technol, v. 48, p. 264-271, 2008 .

16. MILlidGE, J. Plantas Anuais: Guia Prático, São Paulo: Nobel, 1999.

17. FELIPPE, G. Entre o jardim e a horta, São Paulo: Editora Senac, 2004.

18. PEIXOTO, A.M., TOLEDO, F.F. de, REICHARD, K., SOUZA, J.S.I. de Enciclopédia Agrícola Brasileira:C-D. São Paulo: Editora da Universidade de São Paulo, 1998.

19. BARROS, L., FALCÃO, BARROS, L., FALCÃO, S., BAPTISTA, P., FREIRE, C., VILAS-BOAS, M., FERREIRA, I.C.F.R., Antioxidant activity of Agaricus sp. mushrooms by chemical, biochemical and electrochemical assays. Food Chemistry, v. 111, p. 61-66, 2008. 
20. BARROS, L.,CABRITA, L., VILAS BOAS, M., CARVALHO, A. M., FERREIRA, I. C. F. R. Chemical, biochemical and electrochemical assays to evaluate phytochemicals and antioxidant activity of wild plants. Food Chemistry, v. 127, p. 1600-1608, 2011.

21. BARREIRA, J. C. M., FERREIRA, I. C. F. R., OLIVEIRA, M. B. P. P., PEREIRA, J. A. Antioxidant activities of the extracts from chestnut flower, leaf, skins and fruit. Food Chemistry, v. 107, p. 1106-1113, 2008.

22. FANARO, G. B., HASSIMOTTO, N. M. A., BASTOS, D. H. M., VILLAVICENCIO, A. L. C. H. Effects of $\gamma$-radiation on microbial load and antioxidant proprieties in black tea irradiated with different water activities, Radiat Phys Chem, v. 97, p. 217-222, 2014.

23. FURGERI, C., NUNES, T. C. F., FANARO, G. B.,; SOUZA, M. F. F., BASTOS, D. H. M., VILLAVICENCIO, A. L. C. H. Evaluation of phenolic compounds in maté (Ilex paraguariensis) processed by gamma radiation. Radiat Phys Chem, v. 78, p. 639-641, 2009.

24. KOIKE, A., BARREIRA, J. C. M., BARROS, L., SANTOS-BUELGA, C., VILLAVICENCIO, A. L. C. H., FERREIRA, I. C. F. R. Irradiation as a novel approach to improve quality of Tropaeolum majus L. flowers: Benefits in phenolic profiles and antioxidant activity. Innov Food Sci \& Emerg. Technol, v. 30, p. 138-144, 2015. 